\title{
The Impact of Felling Method, Bunch Size, Slope Degree and Skidding Area on Productivity and Costs of Skidding in a Eucalyptus Plantation
}

\author{
Ricardo Hideaki Miyajima, Paulo Torres Fenner, Gislaine Cristina Batistela, \\ Danilo Simões
}

\begin{abstract}
Grapple skidder is a machine designed for the extraction of tree bunches after felling. Several factors influence its technical performance and costs such as terrain slope, operator experience time, machine type, and the size of tree bunches for each operating cycle, among others. Thus, it becomes necessary to weigh the variables that most influence the productivity and costs of the grapple skidder. So, the main objective was evaluated according to the influence of bunch size using two feller bunchers with distinct technical characteristics, two slope classes and two skidding areas on the productivity and machine production cost in a Eucalyptus plantation. For the analysis of the productivity, the study of time and method was applied and the scheduled machine cost per hour was based on the Food and Agriculture Organization of the United Nations methods. When analyzing the results, it was found that the operational elements moving without load (MWoL) and moving with load (MWL) were the ones that spend the most time in the operational cycle of the grapple skidder. Among the cost components, monetary expenditure on fuel and operator labor were the most influential in the scheduled machine cost per hour. In conclusion, the tree bunches and slope class influenced the productivity and, consequently, the cost of the skidding operation.
\end{abstract}

Keywords: forestry, time and motion, wood harvesting, production cost, optimization

\section{Introduction}

The use of mechanization in wood harvesting was an important advance for the forestry sector, which allowed better working conditions for operators, increased productivity and reduced costs. Consequently, improvements related to mechanized wood harvesting provided knowledge of information regarding the productivity and costs of a particular machine and/ or system, i.e., the reliability of these two pieces of information is fundamental for a better understanding of the productive system.

Thus, it can be observed that the mechanization of the wood harvesting activity goes through major innovations and technological advances (Simões et al. 2014, Di Fulvio et al. 2017, Kaakkurivaara and Kaakkurivaara 2018), but for this to occur, it is important to under- stand the processes, stages and work involved in this segment (Lindroos et al. 2017, Schweier et al. 2018, Blagojevic et al. 2019, Kizha et al. 2020), as well as factors involved in assessing forest planning (Mousavi et al. 2011, Bodaghi et al. 2018, Holzleitner et al. 2018, Santos et al. 2019). Although changes are often observed, culminating in the evolution of forest operations, differences in machine production costs may occur due to machine models or wood harvesting methods applied.

One of the forest machines currently used is the grapple skidder, which removes bunches or logs from the felling site to a forest yard or to the edges of the fields. The grapple skidder transports trees from a felling area to the roadside or into an intermediate yard, being a versatile machine that allows great mobility 
within the cutting area and also allows the dragging of large volumes of wood (Behjou et al. 2008, Jour Gholami and Majnounian 2008, Bavaghar et al. 2010, Lima and Leite 2014).

In this way, logging is one of the steps influenced by factors such as machine type, slope, operator experience, wood purpose, forest type, spacing, relief, climate, soil type, available resources and others (Egan 2003, Oliveira et al. 2009, Mousavi et al. 2012, Maesano et al. 2013, Santos et al. 2013, Marčeta et al. 2014, Seixas and Castro 2014, Đuka et al. 2018).

So, considering the most significant variables, their relation with productivity and costs related to wood harvesting, as well as timber extraction and its variables becomes relevant (Najafi et al. 2007, Lotfalian et al. 2011, Borz et al. 2013, Ackerman et al. 2014, Ezzati et al. 2015, Rudek et al. 2019, Stang et al. 2019).

In addition to the importance of these variables in the productivity and hourly cost of the grapple skidder, the costs of production must also be evaluated with due care, since they are essential parts in the composition of the final cost of the product, allowing forest managers an understanding and options for decision making (Mac Donagh et al. 2017, Timofte and Enescu 2019, Holm et al. 2020).

Given that, there is a hypothesis that there is impact of timber bunching on productivity and costs in the grapple skidder logging operation. Therefore, the objective was to evaluate the influence of bunch size using two feller-bunchers with distinct technical characteristics, two slope classes and two skidding area on the productivity and costs in a Eucalyptus forest.

\section{Materials and Methods}

\subsection{Study Area}

The study was carried out in a Eucalyptus forest, located at the geographic coordinates $22^{\circ} 84^{\prime}$ of south latitude and $48^{\circ} 34^{\prime}$ of west longitude, in São Paulo State, Brazil. The eucalyptus plantation had an initial planting space of $3 \times 2 \mathrm{~m}$, 6 years old, average diameter at breast-height (DBH) $14.95 \pm 3.62 \mathrm{~cm}$, average height $20.87 \pm 3.28 \mathrm{~m}$, and individual average volume $0.20 \mathrm{~m}^{3}$ (merchantable timber). The individual tree volume was calculated through the Schumacher and Hall model from the forest inventory, by randomized plots, each one consisting of $400 \mathrm{~m}^{2}$. As a result, a total of 10 diameter classes were obtained, and then, rigorous cubing of five trees was carried out for each diametric class (Husch et al. 2003).
The slope classes in the study were labeled according to the Brazilian soil classification. Thus, they were characterized in Class 1: slope from 0 to $3 \%$ (flat); Class 2: slope from 3.1 to $8 \%$ (mildly undulated; Santos et al. 2018). In both slope classes, the extraction was carried out on a slope.

\subsection{Data Collection}

The applied harvesting system was the full tree, thus, felling was performed by a feller-buncher. The wood was extracted by a John Deere $848 \mathrm{H}$ grapple skidder, four-wheel drive, with $200 \mathrm{hp}$ motor and pneumatic wheels, with a grip load-bearing capacity of $1.5 \mathrm{~m}^{2}$ and a purchase price of USD 245,601.06.

The grapple skidder extracted trees from the plot to the edge of the plantation, that is, to the roadside. Generally, the machine accumulated and carried two tree bunches per cycle, previously formed by two feller-bunchers.

For felling two machines were used: Caterpillar (feller-buncher 1, FB 1) and John Deere (feller-buncher 2, FB 2):

$\Rightarrow$ FB 1 - Caterpillar, model 320 D FM, was with 5197 cumulative hours of use, $147 \mathrm{hp}$ rated power motor, tracked undercarriage, crane with maximum reach of $5.90 \mathrm{~m}$ and Quadco model cutting head, with a cutting capacity of $457 \mathrm{~mm}$, accumulation capacity of $0.28 \mathrm{~m}^{2}$

$\Rightarrow$ FB 2 - John Deere model 903 k, was with 13,241 cumulative hours of use, $300 \mathrm{hp}$ rated power motor, tracked undercarriage, crane with maximum reach of $6.71 \mathrm{~m}$ and FS22B model forest implement, $558 \mathrm{~mm}$ cutting capacity, $0.48 \mathrm{~m}^{2}$ build capacity.

The skidding area depended on the number of tree rows being felled: SA1: skidding area composed of tree bunches, in which trees were cut in a three-rows operation area, and SA2: skidding area composed of tree bunches, where the tree felling was performed in a four-rows operation area. In both operational situations, the skidder carried out the dragging of two bunches, previously placed on the ground by the feller-bunchers, in both operational situations - SA1 and SA2.

The time data were collected through time and methods study, through the continuous time method. The grapple skidder operating cycle was divided into work elements, which were carried out in a regular sequence. The operating cycle consisted of the time taken to perform the following operational elements (OE): moving without load (MWoL), timber loading (TL), moving with load (MWL), and timber unloading 
(TU). After the completion of the operational element (TU), the number of trees for each operational cycle was counted.

120 operating cycles were observed (pilot study) to determine the sample size, i.e. to determine the maximum allowed difference between the population mean and the sample mean, according to Eq. 1, with a confidence level of $95 \%$ and sampling error of $5 \%$ as proposed by Stevenson (2001).

$$
n=\left(\frac{z s}{a \bar{x}}\right)^{2}
$$

Where:

$\begin{array}{ll}n & \begin{array}{l}\text { sample size } \\ \text { obtained constant from the desired trust level, } \\ \text { considering the standard normal distribution } \\ (1.96)\end{array} \\ s & \begin{array}{l}\text { sample standard deviation } \\ a\end{array} \\ \bar{x} & \text { final desired precision (5\%) } \\ & \text { sample mean. }\end{array}$

\subsection{Technical Analysis}

The productivity ( $P$ Eq. 2 ) is a relation between the volume of wood extracted (number of trees per cycle $x$ individual average volume) by the forest machine measured in cubic meters and the productive machine hour $(P M H)$.

$$
P=\frac{V_{\text {wood }}}{P M H}
$$

Where:

$P \quad$ productivity of machine, $\mathrm{m}^{3} \mathrm{~h}^{-1}$

$V_{\text {wood }} \quad$ volume of extracted wood, $\mathrm{m}^{3}$

PMH productive machine hour (without delays or interruptions), $\mathrm{h}$.

\subsection{Economic Analysis}

The economic analysis was based on US dollar, according to the official currency value of the Central Bank of Brazil. Thus, the foreign currency price measured in units and fractions of the national currency was considered as exchange rate, which was $\mathrm{R} \$ 3.3133$ on April 3, 2019, in alignment with data provided by the Central Bank of Brazil (2019).

The scheduled machine cost per hour of the grapple skidder was estimated by the accounting method in accordance with the cost control methods applied to the mechanized forest harvest recommended by the Food and Agriculture Organization of the United Nations (FAO 1992), therefore classified into fixed depreciation costs, interest on capital, labor, insurance and property taxes. Variable costs included monetary values for fuel, maintenance and repairs, spare parts and lubricating oils and greases.

Grapple skidder economic life was estimated at five years with resale value of $20 \%$ of the purchase price. For social charges, $134 \%$ value was adopted regarding the machine operator salary. Considering the rate of return required for capital remuneration, i.e. the opportunity cost of financing, the weighted average cost of capital (WACC) was applied, determined by the equity weights and third-party capital.

The cost of third-party capital was represented by the expected risk-adjusted return on the transaction; consequently, the amount was to be equivalent to the fixed income rate issued by the US Treasury Department, as it is considered a risk-free interest rate, reasonably integrated into the global capital market. Given that, it was possible to calculate the WACC (Eq. 3):

$$
W A C C=k_{\mathrm{b}}(1-\tau) \frac{B}{B+S}+k_{\mathrm{s}} \frac{S}{B+S}
$$

Where:

$$
\begin{array}{ll}
k_{\mathrm{b}} & \text { third-party capital cost } \\
\tau & \text { income tax rate } \\
B & \text { holders' wealth } \\
S & \text { present value of shareholders' wealth } \\
k_{\mathrm{s}} & \text { shareholders' capital cost. }
\end{array}
$$

Given that, the cost of shareholders' capital, which, according to Copeland et al. (2002), is the most difficult to estimate since it cannot be directly observed in the market, was calculated by using the Capital Asset Pricing Model (CAPM, Eq. 4):

$$
k_{\mathrm{s}}=r_{\mathrm{f}}+\beta\left(r_{\mathrm{m}}-r_{\mathrm{f}}\right)+\lambda
$$

Where:

$r_{\mathrm{f}} \quad$ return tax of a risk-free asset

$\beta \quad$ systematic coefficient in wood, paper, cellulose segment

$\mathrm{r}_{\mathrm{m}} \quad$ return rate of market portfolio

$\left(r_{\mathrm{m}}-r_{\mathrm{f}}\right)$ market risk premium

$\lambda \quad$ country risk premium.

The machine production cost (MPC), i.e. wood extraction, was calculated as a relation between scheduled machine cost per hour and productivity (Eq. 5):

Where:

$$
M P C=\frac{S M C H}{P}
$$

MPC machine production cost, USD $\mathrm{m}^{-3}$

$S M C H$ scheduled machine cost per hour, $\mathrm{USD} \mathrm{h}^{-1}$. 


\subsection{Statistical Analysis}

In this experiment, three independent factors were considered at two levels, each described by: factor A referring to the tree bunches, factor B referring to the slope classes of the terrain and factor $C$ referring the skidding area. In this scenario, the combinations of the levels of the factors resulted in the treatments of the experiment, characterized as a factorial scheme $2^{3}$, arranged in a completely randomized design (CRD).

Thus, the element $y_{\mathrm{ijkl}}$ represents the $l$-th repetition $\left(l=1,2, \ldots, n_{\mathrm{ijk}}\right.$, where $n_{\mathrm{ijk}}$ is the number of observations per treatment) of the $i$-th level of factor A $(i=1,2), j$-th level of factor $\mathrm{B}(j=1,2)$ and $k$-th level of factor $\mathrm{C}(k=1,2)$. According to Montgomery (2017), the general model of the response variable is given in Eq. 6:

$y_{\mathrm{ijkl}}=$

$=\mu+\tau_{\mathrm{i}}+\beta_{\mathrm{j}}+\gamma_{\mathrm{k}}+(\tau \beta)_{\mathrm{ij}}+(\tau \gamma)_{\mathrm{ik}}+(\beta \gamma)_{\mathrm{jk}}+(\tau \beta \gamma)_{\mathrm{ijk}}+\varepsilon_{\mathrm{ijkl}}$
Where:

$\mu \quad$ overall mean effect;

$\tau_{\mathrm{i}} \quad$ effect of the $\mathrm{i}$-th level of factor $\mathrm{A}$

$\beta_{\mathrm{j}} \quad$ effect of the $\mathrm{j}$-th level of factor $\mathrm{B}$

$\gamma_{k} \quad$ effect of the $k$-th level of factor $C$

$(\tau \beta)_{\mathrm{ij}} \quad$ effect of interaction between $\tau_{\mathrm{i}}$ and $\beta_{\mathrm{j}}$

$(\tau \gamma)_{\mathrm{ik}} \quad$ effect of interaction between $\tau_{\mathrm{i}}$ and $\gamma_{\mathrm{k}}$

$(\beta \gamma)_{\mathrm{jk}} \quad$ effect of interaction between $\beta_{\mathrm{j}}$ and $\gamma_{\mathrm{k}}$

$(\tau \beta \gamma)_{\mathrm{ijk}}$ effect of interaction between $\tau_{\mathrm{i},} \beta_{\mathrm{j}}$ and $\gamma_{\mathrm{k}}$

$\varepsilon_{\mathrm{ijkl}} \quad$ random error component.

The operating cycle element time, productivity and cost of the skidding operation $\left(\right.$ per $\mathrm{m}^{3}$ ) evaluated in these different treatments were compared through the three factor analysis of variance model (ANOVA), complemented by the Tukey-Kramer test for multiple comparisons, considering a 5\% significance level (Montgomery 2017). Statistical analyses were performed using genmod procedure of the statistical

Table 1 Average time and standard deviation of operational cycle elements of tree extraction carried out by a grapple skidder

\begin{tabular}{|c|c|c|c|c|c|c|}
\hline TB & SC & SA & MWoL & MWL & $\mathrm{TL}$ & TU \\
\hline \multirow{8}{*}{1} & \multirow{4}{*}{1} & \multirow{2}{*}{ SA1 } & 51.62 a A $\alpha$ & 54.95 a $\mathrm{A} \alpha$ & 38.00 a $\mathrm{A} \alpha$ & 4.00 a $\mathrm{A} \alpha$ \\
\hline & & & (15.93) & $(9.46)$ & (13.13) & $(0.78)$ \\
\hline & & \multirow{2}{*}{ SA2 } & 56.51 а $\mathrm{A} \beta$ & 61.44 a $\mathrm{A} \alpha$ & 36.00 a A $\alpha$ & 4.23 a $\mathrm{A} \alpha$ \\
\hline & & & $(11.58)$ & (8.65) & (15.82) & $(1.83)$ \\
\hline & \multirow{4}{*}{2} & \multirow{2}{*}{ SA1 } & 56.26 a A $\alpha$ & 87.32 b B $\beta$ & 44.03 а $\mathrm{A} \beta$ & 3.71 a $\mathrm{A} \alpha$ \\
\hline & & & (21.82) & (30.47) & (16.69) & $(0.58)$ \\
\hline & & \multirow{2}{*}{ SA2 } & 59.78 a $\mathrm{A} \alpha$ & 72.80 a $\mathrm{A} \alpha$ & 45.04 a B $\alpha$ & 3.91 a $\mathrm{A} \alpha$ \\
\hline & & & (20.94) & $(34.58)$ & $(30.06)$ & $(0.73)$ \\
\hline \multirow{8}{*}{2} & \multirow{4}{*}{1} & \multirow{2}{*}{ SA1 } & 65.63 a $\mathrm{A} \alpha$ & 91.40 a B $\beta$ & $42.55 \mathrm{a} \mathrm{B} \alpha$ & 4.30 a $\mathrm{A} \alpha$ \\
\hline & & & (27.06) & (42.15) & (25.75) & $(0.56)$ \\
\hline & & \multirow{2}{*}{ SA2 } & 66.96 a $\mathrm{A} \alpha$ & 97.20 a B $\beta$ & 39.39 a $\mathrm{A} \alpha$ & 4.22 a $\mathrm{A} \alpha$ \\
\hline & & & (26.58) & (40.22) & (19.54) & $(0.50)$ \\
\hline & \multirow{4}{*}{2} & \multirow{2}{*}{ SA1 } & 56.36 a $\mathrm{A} \alpha$ & 72.00 a A $\alpha$ & 32.78 a $\mathrm{A} \alpha$ & 4.03 a $\mathrm{A} \alpha$ \\
\hline & & & $(24.86)$ & $(23.41)$ & $(12.03)$ & $(0.61)$ \\
\hline & & \multirow{2}{*}{ SA2 } & 60.10 a $\mathrm{A} \alpha$ & 84.01 a $\mathrm{A} \alpha$ & 39.45 a A $\alpha$ & 4.31 а $\mathrm{A} \beta$ \\
\hline & & & (23.19) & (34.64) & (15.81) & $(0.56)$ \\
\hline
\end{tabular}

Lower case letters compare the skidding area, upper-case letters compare slope classes, Greek letters compare tree bunches; all according to the Tukey-Kramer test with $5 \%$ significance.

TB - Tree bunches 1: formed by feller-buncher 1; Tree bunches 2: formed by the feller-buncher 2

$\mathrm{SC}$ - slope class, 1 (flat); 2 (mildly undulated)

SA - skidding area; SA1: three-rows operation area, SA2: four-rows operation area

MWoL - move without load

$\mathrm{TL}$ - timber loading

MWL - move with load

TU - timber unloading 
software SAS - Free Statistical Software, SAS, University Edition.

Moreover, for data collected through KolmogorovSmirnov and Bartlett tests, it was checked whether the assumptions of normality and homogeneity of variances were verified; however, according to the Central Limit Theorem (Mood et al. 1974, RAO 2001) whatever the distribution of the variable of interest for large samples $(n>30)$, the mean sample distribution will tend to a normal distribution, as the sample size grows. All the statistical analyses were performed using $\mathrm{R}$ software version 3.5.2 ( $\mathrm{R}$ Development Core Team, 2018).

\section{Results}

\subsection{Time of Elements of Operational Cycle}

336 operational cycles were observed, which resulted in the extraction of $1616.60 \mathrm{~m}^{3}$ of wood, with sampling error of $2.23 \%$, which allowed the sample size to be greater than the number of minimum cycles to be observed with statistical legitimacy.

The elements considered in the grapple skidder operation (Table 1) can be verified, according to operational conditions.

By analyzing the skidding area factor for performing operational elements, statistically significant difference $(p<0.05)$ was found only for one situation and this difference was observed for the ML element for the operating condition composed of tree bunches 1 and slope class 2 . Moreover, no significant differences were found, indicating that the skidding area composed of tree bunches referring to the three and four lines working area performed by the feller-bunchers did not affect the performance of the grapple skidder operational elements under the different operating conditions evaluated.

For the effect of slope class in the performance of the move with load (MWL) and timber loading (TL), statistically significant differences $(p<0.05)$ were observed in some operating conditions. This fact cannot explain the slope class influence for the performance of all operational elements; a possible explanation would be related to the fact that they are close slope classes.

For analyzing the factor tree bunches in the average time operation conditions, statistically significant differences $(p<0.05)$ were found for all elements. The trees bunches formed in the cutting stage by two fellerbunchers, with different technical characteristics, may have influenced the extraction operation.

\subsection{Productivity}

The productivity is essential for managers when making decisions about supply and logistics. Thus, by analyzing the productivity (Table 2), it can be checked that, for the skidding area factor, it was not possible to identify statistically significant difference $(p<0.05)$ in any condition of machine operation.

Table 2 Productivity and standard deviation $\left(\mathrm{m}^{3} \mathrm{~h}^{-1}\right)$ of tree extractions, performed by a grapple skidder

\begin{tabular}{|c|c|c|c|}
\hline \multirow{2}{*}{ TB } & \multirow{2}{*}{ SC } & \multicolumn{2}{|c|}{ SA } \\
\hline & & SA1 & SA2 \\
\hline \multirow{2}{*}{1} & 1 & $\begin{array}{c}126.12 \text { a B } \beta \\
(24.52)\end{array}$ & $\begin{array}{c}128.51 \text { a B } \beta \\
(23.56)\end{array}$ \\
\hline & 2 & $\begin{array}{c}98.56 \text { a A } \alpha \\
(31.29) \\
\end{array}$ & $\begin{array}{c}103.04 \text { a A } \alpha \\
(29.68)\end{array}$ \\
\hline \multirow{2}{*}{2} & 1 & $\begin{array}{c}98.37 \text { a A } \alpha \\
(47.63)\end{array}$ & $\begin{array}{c}91.57 \text { a A } \alpha \\
(35.89)\end{array}$ \\
\hline & 2 & $\begin{array}{c}108.31 \text { a } \mathrm{A} \alpha \\
(34.73)\end{array}$ & $\begin{array}{c}97.07 \text { a } \mathrm{A} \alpha \\
(32.11)\end{array}$ \\
\hline
\end{tabular}

Lower case letters compare the skidding area, upper-case letters compare slope classes, Greek letters compare the tree bunches; all according to the Tukey-Kramer test with $5 \%$ significance.

TB - Tree bunches 1: formed by feller-buncher 1; Tree bunches 2: formed by the fellerbuncher 2

SC - slope class, 1 (flat); 2 (mildly undulated)

SA - skidding area; SA1: three-rows operation area, SA2: four-rows operation area

As to the slope class factor, statistically significant differences were also found $(p<0.05)$ for the following operating conditions (Tree bunches 1 in E1 and E2), with the highest productivity for $\mathrm{SC} 1$, for the operating condition in which the tree bunches were formed by the feller-buncher 1 .

When analyzing the tree bunches factor, in the following operational conditions: SC1 and EF1, SC1 and $\mathrm{EF} 2$, statistically significant differences $(p<0.05)$ were found with higher productivity of the grapple skidder in synergy with Tree bunches 1, which were formed by the machine with feller-buncher 1 .

\subsection{Cost Estimate}

Cost-related pieces of information, such as the hourly programmed cost of the machine, as well as the cost of production, are economically essential, since knowledge of this information assists in the planning of mechanized wood harvesting, by choosing the type of machine and even the harvest mode. Accordingly, the rate of return on the capital required for the acquisition of the grapple skidder, calculated through the $W A C C$, is based on one of the assumptions - the riskfree interest rate, which was $2.36 \%$ per year. 
Table 3 Average cost of skidding operation and standard deviation $\left(U S D m^{-3}\right)$

\begin{tabular}{|c|c|c|c|}
\hline \multirow{2}{*}{ TB } & \multirow{2}{*}{ SC } & \multicolumn{2}{|c|}{ SA } \\
\hline & & SA1 & SA2 \\
\hline \multirow{2}{*}{1} & 1 & $\begin{array}{c}0.59 \text { a A } \alpha \\
(0.15)\end{array}$ & $\begin{array}{c}0.58 \text { a A } \alpha \\
(0.16)\end{array}$ \\
\hline & 2 & $\begin{array}{c}0.79 \text { a B } \alpha \\
(0.25)\end{array}$ & $\begin{array}{c}0.74 \text { a B } \alpha \\
(0.21)\end{array}$ \\
\hline \multirow{2}{*}{2} & 1 & $\begin{array}{c}0.88 \text { а } \mathrm{B} \beta \\
(0.38)\end{array}$ & $\begin{array}{c}0.88 \text { a } A \beta \\
(0.30)\end{array}$ \\
\hline & 2 & $\begin{array}{c}0.72 \text { a A } \alpha \\
(0.24)\end{array}$ & $\begin{array}{c}0.81 \text { a A } \alpha \\
(0.26)\end{array}$ \\
\hline
\end{tabular}

Lower case letters compare the skidding area, upper-case letters compare slope classes, Greek letters compare the tree bunches; all according to the Tukey-Kramer test with 5\% significance.

TB - Tree bunches 1: formed by feller-buncher 1; Tree bunches 2: formed by the fellerbuncher 2

SC - slope class, 1 (flat); 2 (mildly undulated)

SA - skidding area; SA1: three-rows operation area, SA2: four-rows operation area

The calculation of the systematic coefficient of the asset was made from the total average beta for the sector under analysis, that is, for the Brazilian forest sector, which resulted in an average unleveraged beta of 0.33 , and then, a re-leveraged beta of 0.42 . The fiveyear annualized return, which was $5.06 \%$ according to the S\&P Global Timber and Forestry Index, was also considered.

Finally, the country-risk premium (Brazil), which was $2.37 \%$, was calculated using the geometric average of the Emerging Markets Bond Index $-E M B I+B r$. Consequently, the shareholders' capital of $6.85 \%$ was obtained, considering the third-party capital cost of $5.96 \%$ and the proportion for debt financed asset of $40.84 \%$, the WACC was $9.16 \%$ per year.

The scheduled machine cost per hour was USD $70.76 \mathrm{~h}^{-1}$. Among the cost components, fuel, labor and depreciation costs were the highest, accounting for $75.16 \%$ of the grapple skidder hourly programmed cost.

A possible explanation for the variation in the hourly programmed cost of the grapple skidder may be related to factors such as time, rate, monetary amounts spent on labor, depreciation of the machine, social charges and fuel costs.

When analyzing the impact of the skidding area factor on the machine production cost (MPC) (Table 3), there were no statistically significant differences $(p>0.05)$. The tree bunches formed by those two fellerbunchers from three and four tree rows did not influence the machine production cost at the extraction stage.
As to the slope class, statistically significant differences were found $(p<0.05)$ in the cost of the skidding operation

\section{Discussion}

Regarding the impact of slope class on the time of realization of the operational elements: statistically significant differences $(p<0.05)$ were only found in some situations, differently from the results found by Behjou et al. (2008) and Diniz et al. (2019), who analyzed the grapple skidder in the slopes from 3\% to $30 \%$.

When assessing the effect of the tree bunches, it was also found that for some operational conditions this factor was significant. The tree bunches previously formed by two feller-bunchers with different technical characteristics influenced the time of realization of the operational elements of the grapple skidder; therefore, the number of trees per bunches may be the factor that explains these differences, similar to the results found by Strandgard et al. (2015).

The number of tree rows (three and four) taken as tree bunches did not have an impact on the productivity of the grapple skidder. This can be explained by the fact that for both skidding areas, the grapple skidder always formed its load with two bunches from both feller-bunchers.

However, it is important to emphasize that the size of the tree bunches must be the most appropriate for the optimization in grapple skidder operation; this can positively and negatively influence the productivity, which can be corroborated by Ackerman et al. (2014).

The extraction operation may have been affected by the cutting operation for this combination of machines, and for these operational conditions the slope class may have been influencing the productivity. Gilanipoor et al. (2012a) and Vusić et al. (2013) confirmed the influence of slope classes on the productivity. This was not observed for the operating condition in which the cut was performed by the feller-buncher " 2 «, nor was the slope effect significant for this operation condition.

A possible explanation may be attributed to the shorter effective time and to shorter time to perform the MWL and ML operating elements. The tree bunches were considered an important variable that can influence the grapple skidder operation time, as well as the respective productivity according to Wang et al. (2004) and Hiesl et al. (2015).

When analyzing the factors tree bunches (TB1) and tree bunches (TB2), slope class was significant. According to Kulak et al. (2017), the number of trees per cycle, volume of wood per cycle, extraction distance and ground conditions (Proto et al. 2018) were the most 
significant factors affecting productivity. Besides that, it was also found that slope class influenced the productivity and the machine production cost (Gilanipoor et al. 2012b, Lopes and Diniz 2015).

In the evaluation of a cable skidder, the distance was the most relevant factor for the performance of all operational elements, and the slope of the terrain interfered in winching operation (Borz et al. 2014). The volume of wood was the most significant factor in the productivity and cycle time of cable skidder (Mousavi 2012). The same fact was observed by Lopes et al. (2014), who evaluated the productivity of the grapple skidder with different types of wheelsets.

When analyzing machine cost per hour, it was found to be superior to the one calculated by Rocha et al. (2009), which was USD $57.48 \mathrm{~h}^{-1}$ for similar conditions of slope and forest. According to the study carried out by Pereira et al. (2015), it was USD $65.43 \mathrm{~h}^{-1}$ on mildly undulating terrain, though. However, the scheduled machine cost per hour was lower than the results found by authors Nikooy et al. (2013) for a grapple skidder, and by Oliveira et al. (2006) for a clambunk skidder in a Eucalyptus forest and undulating terrain. The differences in scheduled machine cost are due to the different methods with different components.

When analyzing the effect of the tree bunches size formed by the feller-buncher for the following operational conditions: SC1 and E1 and for SC1 and E2, differences were statistically significant $(p<0.05)$. Machine production cost was lower for tree bunches $» 1 \ll$, which may be explained by the higher productivity, shorter effective time performing the machine operational cycle and the number of trees. Besides that, the cutting operation influenced the extraction operation, mainly by the number of trees per bunches (Wang et al. 2004, Hiesl and Benjamin 2015).

The number of trees per cycle was the most significant factor for productivity and machine production cost according to (Hejazian et al. 2013). In addition, slope class, moving distance and volume of wood per tree were the most significant factors according to Leite et al. (2014), and extraction distance according to some other authors (Ghaffariyan et al. 2012, Spinelli and Magagnotti 2012, Han et al. 2018).

\section{Conclusions}

Among the analyzed factors, the tree bunches and slope class influenced the grapple skidder productivity. In the condition of tree bunches »1 « (TB1) formed by feller-buncher $" 1$ «, the average time for the realization of the skidding elements, MWoL and MWL took less time in comparison with tree bunches $» 2 «$ (TB2) formed by feller-buncher $» 2 \ll$.
The productivity in operation condition for tree bunches »1«(TB1) formed by feller-buncher »1« was $18.84 \%$ higher compared to the operation condition for tree bunches $» 2$ «(TB2) formed by feller-buncher $» 2 \ll$. Therefore, the grapple skidder production cost in operation condition for tree bunches »1« was $25.22 \%$ lower compared to the operation condition for tree bunches $» 2 \ll$.

\section{Acknowledgements}

This work was carried out with the support of the Higher Education Personnel Improvement Coordination - Brazil (CAPES) - Financing Code 001.

\section{References}

Ackerman, P., Pulkki, R., Gleasure, E., 2014: Modelling of wander ratios, travel speeds and productivity of cable and grapple skidders in softwood sawtimber operations in South Africa. Southern Forests: a Journal of Forest Science 76(2): 101-110. https://doi.org/10.2989/20702620.2014.917355

Ackerman, P., Belbo, H., Eliasson, L., Jong, A., Lazdins, A., Lyons, J., 2014: The COST model for calculation of forest operations costs. International Journal of Forest Engineering 25(1): 75-81. https://www.tandfonline.com/doi/full/10.1080/1 4942119.2014.903711

Bavaghar, M.P., Sobhani, H., Feghhi, J., Darvishsefat, A.A., Marvi Mohajer, M.R., 2010: Comprehensive productivity models for tracked and wheeled skidders in the Hyrcanian Forest of Iran. Research Journal of Forestry 4(2): 65-71. https://scialert. net/abstract/?doi=rjf.2010.65.71

Behjou, F.K., Majnounian, B., Namiranian, M., Dvorak, J., 2008 : Time studying and skidding capacity of wheeled skidder timberjack 450c in Caspian forests. Journal of Forest Science 54(4): 183-188. https://doi.org/10.17221/5/2008-JFS

Blagojevic, B., Johnsson, R., Bjorheden, R., Nordstrom, E.M., Lindroos, O., 2019: Multi-criteria decision analysis (MCDA) in forest operations-an introductional review. Croatian Journal of Forest Engineering 40(1): 191-205.

Bodaghi, A.I., Nikooy, M., Naghdi, R., Venanzi, R., Latterini, F., Tavankar, F., Picchio, R., 2018: Ground-based extraction on salvage logging in two high forests: A productivity and cost analysis. Forests 9(12): 729. https://doi.org/10.3390/f9120729

Borz, S.A., Dinulica, F., Birda, M., Ignea, G.H., Clobanu, V.D., Popa, B., 2013: Time consumption and productivity of skidding silver fir (Abies alba Mill.) round wood in reduced accessibility conditions: a case study in windthrow salvage logging form Romanian Carpathians. Annals of Forest Research 56(2): 363-375. https://doi.org/10.15287/afr.2013.38

Borz, S.A., Ignea, G., Popa, B., 2014: Modelling and comparing timber winching performance in windthrow and uniform selective cuttings for two Romanian skidders. Journal of Forest Research 19(6): 473-482. https://doi.org/10.1007/s10310-0140439-0 
Central Bank of Brazil, 2019: Coin Conversion. Acessed June 05, 2019.

Copeland, T.E., Murrin, J., Koller, T., 2002: Valuation of companies - valuation: calculating and managing the value of companies 3 ed. São Paulo: Pearson, 516 p.

Di Fulvio, F., Abbas, D., Spinelli, R., Acuna, M., Ackerman, P., Lindroos, O., 2017: Benchmarketing technical and cost factors in forest felling and processing operations in different global regions during the period 2013-2014. Int. J. For. Eng. 28(2): 94-105. https://doi.org/10.1080/14942119.2017.1311559

Diniz, C.C.C., Nakajima, N.Y., Robert, R.C.G., Dolácio, C.J.F., Silva, F.A., Balensiefer, D.F., 2019: Performance of grapple skidder in different ground inclinations. Floresta 49(1): 41-48. https://doi.org/10.5380/rf.v49i1.55744

Draper, N.R., Smith, H., 1998: Applied regression analysis. 3. ed. New York: Wiley-Interscience, $736 \mathrm{p}$.

Đuka, A., Poršinsky, T., Pentek, T., Pandur, Z., Vusić, D., Papa, I., 2018: Mobility range of a cable skidder for timber extraction on sloped terrain. Forests 9(9): 1-11. https://doi.org/10.3390/ f9090526

Egan, A.F., 2003: Ground skidding and harvested stand attributes in Appalachians hardwood stands in West Virginia. Forest. Products. Journal 53(9): 59-63.

Ezzati, S., Najafi, A., Yaghini, M., Hashemi, A.A., Bettinger, P., 2015: An optimization model to solve skidding problem in steep slope terrain. Journal of Forest Economics 21(4): 250-268. https://doi.org/10.1016/j.jfe.2015.10.001

Food and Agriculture Organization of the United Nations, 1992: Cost control in forest harvesting and road construction. Rome, Forestry Paper 99, 121 p.

Ghaffariyan, M.R., Acuna, M., Kellog, L., 2012: Productivity of roadside processing system in Western Australia. Silva Balcanica 13(1): 49-60.

Gilanipoor, N., Najafi, A., Heshmat Alvaezin, S.M., 2012a: Productivity and cost of farm tractor skidding. Journal of Forest Science 58(1): 21-26. https://doi.org/10.17221/4804-JFS

Gilanipoor, N., Najafi, A., Heshmat Alvaezin, S.M., 2012b: Optimum combination of animal and farm tractor skidding systems in wood harvesting. Journal of Forest and Wood Products 65(1): 71-82.

Han, H., Chung, W., She, J., Anderson, N., Wells, L., 2018: Productivity and costs of two beetle-kill salvage harvesting methods in Northern Colorado. Forests 9(9): 572. https://doi. org/10.3390/f9090572

Hejazian, M., Lotfalian, M., Hosseini, S.A., Fallah, A., 2013: Analysis and evaluation of ground skidder costs of two stands with respect to production per hour and log quality. Bulletin of Environment, Pharmacology and Life Sciences 2(11): 24-29.

Hiesl, P., Waring, T.M., Benjamin, J.G., 2015: The effect of hardwood component on grapple skidder and stroke delimber idle time and productivity - An agent based model. Computer and Electronics in Agriculture 118: 270-280. https://doi. org/10.1016/j.compag.2015.09.010

Hiesl, P., Benjamin, J.G., 2015: Can technology help improve grapple skidder and stroke delimber interactions? A simulation approach. International Journal of Forest Engineering 26(3): 171-184.
Holm, S., Frutig, F., Lemm, R., Thees, O., Schweier, J., 2020: HeProMo: A decision support tool estimate wood harvesting productivities. Plos One 15(12): 1-19. https://doi.org/10.1371/ journal.pone.0244289

Holzleitner, F., Kastner, M., Stampfer, K., Holler, N., Kanzian, C., 2018: Monitoring cable tensile forces of winch-assist harvest and forwarder operations in steep terrain. Forests 9(2): 1-13. https://doi.org/10.3390/19020053

Husch, B., Beers, T., Kershaw, J., 2003: Forest Mensuration 4 ed. New York: John Wiley and Sons, 443 p.

Jour Gholami, M., Majnounian, B., 2008: Productivity and cost of wheeled skidder in Hyrcanian Forest. International Journal of Natural and Engineering Sciences 2(3): 99-103.

Kaakkurivaara, N., Kaakkurivaara, T., 2018: Productivity and cost analysis of three timber extraction methods on steep terrain in Thailand. Croatian Journal of Forest Engineering 39(2): 213-221.

Kulak, D., Stanczykiewicz, A., Szewczyk, G., 2017: Productivity and time consumption of timber extraction with a grapple skidder in selected pine stands. Croatian Journal of Forest Engineering 38(1): 55-63.

Kizha, A.R., Han, H.S., Anderson, N., Koirala, A., Louis, L.T., 2020: Comparing hot and cold loading in an integrated biomass recovery operation. Forests 11(4): 385. https://doi. org/10.3390/f11040385

Lopes, E.S., Oliveira, D., Sampietro, J.A., 2014: Influence of wheeled types of a skidder on productivity and cost of the forest harvesting. Floresta 44(1): 53-62. http://dx.doi. org/10.5380/rf.v44i1.31356

Lopes, E.S., Diniz, C.C.C., 2015: Productivity of forestry chocker skidder in extraction of wood on steep terrain. Floresta 45(3): 625-634. https://doi.org/10.5380/rf.v45i3.36409

Leite, E.S., Fernandes, H.C., Minette, L.J., Souza, A.P., Leite, H.G., Guedes, I.L., 2014: Modelagem do desempenho da extração de madeira pelo forwarder. Revista Árvore 38(5): 879_ 887. https://doi.org/10.1590/S0100-67622014000500012

Lima, J.S.S., Leite, A.M.P., 2014: Mechanization. In: Machado, C.C. Forest Harvest. 3. ed. Viçosa, MG: UFV 46-73 p.

Lindroos, O., La Hera, P., Haggstrom, C., 2017: Drivers of Advances in Mechanized timber harvesting a selective review of technological innovation. Croatian Journal of Forest Engineering 38(2): 243-258.

Lotfalian, M., Moafi, M., Foumani, B.S., Akbari, R.A., 2011: Time study and skidding capacity of the wheeled skidder timberjack 450C. Journal of Soil Science and Environmental Management 2(7): 120-124. https://doi.org/10.5897/IJSTER.9000035

Lopes, E.S., Oliveira, D., Sampietro, J.A., 2014: Influence of wheeled types of a skidder on productivity and cost of the forest harvesting. Floresta 44(1): 53-62. http://dx.doi. org/10.5380/rf.v44i1.31356

Lopes, E.S., Diniz, C.C.C., 2015: Productivity of forestry chocker skidder in extraction of wood on steep terrain. Floresta 45(3): 625-634. https://doi.org/10.5380/rf.v45i3.36409

Mac Donagh, P., Botta, G., Schlichter, T., Cubbage, F., 2017: Harvesting contractor production cost and costs in forest plantations of Argentina, Brazil, and Uruguay. International 
Journal of Forest Engineering 28(3): 157 -158. https://doi.org/ 10.1080/14942119.2017.1360657

Maesano, M., Picchio, R., Monaco, A.L., Neri, F., Lasserre, B., Marchetti, M., 2013: Productivity and energy consumption in logging operation in a Cameroonian tropical forest. Ecological Engineering 57: 149-153. https://doi.org/10.1016/j.ecoleng.2013.04.013

Marčeta, D., Petković, V., Košir, B., 2014: Comparison of two skidding methods in beech forests in mountainous conditions. Nova mehanizacija šumarstva 35(1): 51-62.

Mood, A.M., Graybill, F.A., Boes, D.C., 1974: Introduction to the theory of statistics. 3 ed. New York: McGraw-Hill, 564 p.

Montgomery, D.C., 2017: Design and analysis of experiments. 9. ed. New York: John Wiley \& Sons, 640 p.

Mousavi, R., Nikouy, M., Uusitalo, J., 2011: Time consumption, productivity, and cost analysis of the motor manual tree felling and processing in the Hyrcanian Forest in Iran. Journal of Forestry Research 22(4): 665-669. https://doi.org/10.1007/s11676011-0208-2

Mousavi, R., Nikooy, M., Nezhad, A.E., Ershadfar, M., 2012: Evaluation of full tree skidding by HSM-904 skidder in patch cutting of aspen plantation in Northern Iran. Journal of Forest Science 58(2): 79-87. https://10.17221/78/2011-JFS

Mousavi, R., 2012: Time consumption, productivity, and cost analysis of skidding in the Hyrcanian forest in Iran. Journal of Forestry Research 23(4): 691-697. https://doi.org/10.1007/ s11676-012-0265-1

Najafi, A., Sobhani, H., Seed, A., Makhdom, M., Marvi Mohajer, M.R., 2007: Time study of skidder HSM 904. Iranian Journal of Natural Resources 60(3): 921-930.

Nikkoy, M., Esmailnezhad, A., Naghdi, R., 2013: Productivity and cost analysis of skidding with timberjack $450 \mathrm{C}$ in forest plantations in Shafaroud watershed, Iran. Journal of Forest Science 59(7): 261-266. https://doi.org/10.17221/19/2013-JFS

Oliveira, R.J., Machado, C.C., Souza, A.P., Leite, H.G., 2006: Technical and economic evaluation of eucalyptus log extraction using a clambunk skidder. Revista Árvore 30(2): 267-275. https://doi.org/10.1590/S0100-67622006000200014

Oliveira, D., Lopes, E.S., Fiedler, N.C., 2009: Technical and economical evaluation of the Forwarder in the extraction of the pine logs. Scientia Forestalis 37(84): 525-533.

Pereira, A.L.N., Lopes, E.S., Dias, A.N., 2015: Technical and cost analysis of feller buncher and skidder on wood harvesting in different stand productivity. Ciência Florestal 25(4): 981989. http://dx.doi.org/10.5902/1980509820659

Proto, A.R., Macri, G., Visser, R., Russo, D., Zimbalatti, G., 2018: Comparison of timber extraction productivity between winch and grapple skidding: A case study in Southern Italian forests. Forests 9(2): 61. https://doi.org/10.3390/f9020061

Rao, C.R., 2001: Linear statistical inference and its applications. 2 ed, New York, John Wiley \& Sons, 625 p.

R Development core team 2018: A language and environment for statistical computing. Vienna, Austria R Foundation for Statistical Computing.
Rocha, E.B., Fiedler, N.C., Alves, R.T., Lopes, E.S., Guimarães, P.P., Peroni, L., 2009: Productivity and costs of a full tree harvesting system. Cerne 15(3): 372-381.

Rudek, A., Lopes, E.S., Arce, J.E., Oliveira Filho, P.C., 2019: Development of mathematical programming model for cable logging system location. Floresta e Ambiente 26(1): 1-9. https:// doi.org/10.1590/2179-8087.054317

Santos, P.H.A., Souza, A.P., Marzano, F.L.C., Minette, L.J., 2013: Productivity and costs of eucalyptus wood extraction with clambunk skidder. Revista Árvore 37(3): 511-518. https:// doi.org/10.1590/S0100-67622013000300014

Santos, H.G., Almeida, J.A., Oliveira, J.B., Lumbreras, J.F., Anjos, L.H.C., Coelho, M.R., Jacomine, P.K.T., Cunha, T.J.F., Oliveira, V.A., 2018: Brazilian Soil Classification System. 5. ed. Brasília: EMBRAPA, 353 p.

Santos, P.A.V.H., Silva, A.C.L., Arce, J.E., Augustynczik, A.L.D., 2019: A mathematical model for the integrated optimization of harvest and transport scheduling of forest products. Forests 10(12): 1110. https://doi.org/10.3390/f10121110

Schweier, J., Spinelli, R., Magagnotti, N., Wolfslehner, B., Lexer, M.J., 2018: Sustainability assessment of alternative thinning operations in mediterranean softwood plantations. Forests 9(7): 375. https://doi.org/10.3390/f9070375

Seixas, F., Castro, G.P., 2014: Extraction. In: Machado, C.C. Forest harvest. 3. ed. Viçosa, MG: UFV, 106-161 p.

Simões, D., Fenner, P.T., Esperancini, M.S.T., 2014: Productivity and costs of feller-buncher and forest processor in stands of eucalyptus in first cut. Ciência Florestal 24(3): 621-630. https://doi.org/10.1590/1980-509820142403010

Spinelli, R., Magagnotti, N., 2012: Wood extraction with farm tractor and sulky: estimating productivity, cost and energy consumption. Small scale forestry 11(1): 73-85. https://doi. org/10.1007/s11842-011-9169-8

Stang, M.B., Arce, J.E., Machado, S.A., Belavenutti, P.H., Fiorentin, L.D., 2019: Spatial forest planning for optimized harvest scheduling. Floresta e Ambiente 26(1): 1-9. https://doi. org/10.1590/2179-8087.010016

Stevenson, W.J., 2001: Administration of production operations 6. ed. Rio de Janeiro: LTC 701 p.

Strandgard, M., Walsh, D., Mitchell, R., 2015: Productivity and cost of whole-tree harvesting without debarking in Eucalyptus nitens plantation in Tasmania, Australia. Southern Forests. 77(3): 173-178. http://dx.doi.org/10.2989/20702620.2014.10016 69

Timofte, A.I., Enescu, C.M., 2019: Economic aspects regarding the extraction of wood using horses: a case study. Scientific Papers Series Management, Economic Engineering in Agriculture and Rural Development 19(3): 599-604.

Vusić, D., Šušnjar, M., Marchi, E., Spina, R., Zečić, Z., Picchio, R., 2013: Skidding operations in thinning and shelterwood cut of mixed stands-work productivity, energy inputs and emissions. Ecological Engineering 61(Part A): 216-223. https:// doi.10.1016/j.ecoleng.2013.09.052

Wang, J., Long, C., Mcneel, J., 2004: Production and cost analysis of a feller-buncher and grapple skidder in central Appalachian hardwood forests. Forest Products Journal 54(12): 159-167. 
(C) 2021 by the authors. Submitted for possible open access publication under the terms and conditions of the Creative Commons Attribution (CC BY) license (http://creativecommons.org/licenses/by/4.0/).

Ricardo Hideaki Miyajima, PhD e-mail: richidetoshimiyajima@hotmail.com Prof. Paulo Torres Fenner, PhD e-mail: paulo.fenner@unesp.br São Paulo State University (Unesp) School of Agriculture, Botucatu Department of Forestry Science, Soil and Environment 3780 Universitária Avenue 18610-034, Botucatu São Paulo BRAZIL

Prof. Gislaine Cristina Batistela, PhD e-mail: gislaine.batistela@unesp.br Prof. Danilo Simões, PhD * e-mail: danilo.simoes@unesp.br São Paulo State University (Unesp) Campus of Itapeva Production Engineering Department 519 Geraldo Alckmin Street 18409-010, Itapeva São Paulo BRAZIL

* Corresponding author 